\title{
鉄道車両のプロダクトライフサイクルと 情報管理
}

Information Management for the Product-Life-Cycle Rolling Stocks
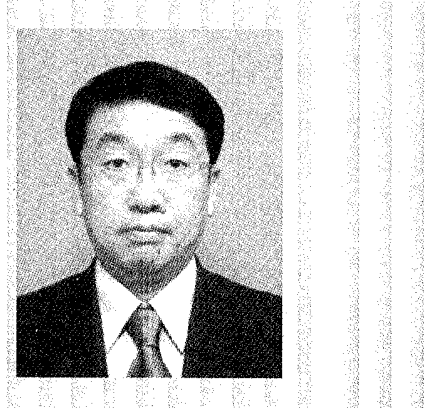

佐藤 裕

Hiroshi SATO

○1954年10月生まれ

1979年早稻田大学理工学研究科修了, 同年旧 国

鉄入社, 1987年東日本旅客鉄道 (株)，1999年 より運輸車両部所属

○研究・専門テーマはは鉄道車而の開発から保全な ど全般の技術

○正員, 東日本旅客鉄道 (株)

( テ151-8578 東京都涉谷区代\& 木2-2-2/

E-mail : h-satou@head.jreast.co.jp)

\section{1 鉄道事業者による車両の新造事業}

1994年より東日本旅客鉄道（株）新津車両製作所におい て，通勤電車の社内製造を開始した。これにより，図 1 に 示すように，開発一設計一製造一使用（運用，保全）～廃 車まで考慮した 20 年以上に及ぶプロダクトライフサイクル という概念 ${ }^{(1)}$ 事業者が鉄道車両に関して一貫して管理す ることとなり, 車両の開発, 適切なメンテナンス手法の導 入, リサイクル・リユース处理等の最適化, そしてライフ サイクルコスト低減等の体系的検討が可能となった。

特に, 新系列車両と呼んでいる京浜東北線用車両を初め とする209系以降の電車では, 開発, 設計と同時に, メン テナンスの考え方を整理し，車両に反映させるものと地上 設備に反映させるものを明確にして, 全体を構築してきた。 車両のメンテナンスフリー化と共に, 修繥を担当する大井 工場に抢いては，新しい発想による新系列車両専用の検査 ラインを構築し, 工場在場日数を大幅に削減することが可 能となり，また，リサイクル可能な材料の使用等について も，保守と製造が一体となって取り組むなど，ライフサイ クル全体での情報交換による技術的取り組みを行えるよう になった。

\section{2 各段階における情報化の取り組み}

このサイクルには，運行～メンテナンスという周期の短 いループと, 改造, 改良によるプロダクトの機能改善とい うループとが混在して，大きな閉ループを構成している。 これらのそれぞれに打いて，情報の統合による業務の最適 化が行われる必要があり，さまざまなシステムが導入され てきている，以下に，鉄道車両ライフサイクルに打ける情 報管理の考え方を述べる。この中でいう「情報化」とは， 「ある目的実現のために必要な情報を, 関係する組織，個 人等において共有することで, 有効かつ効率的にその行為 に資すること」と考元，情報通信技術のハードについては， その手段であることからここでは言及しない。

\section{2-1「設計」「製造」における情報化の取り組み}

前述のように車両新造を開始したことでプロダクトライ フサイクルのすべてを保有することとなったが，このこと は, 今までの車両発注・設計・製造の手順を大きく変ぼう させるものである。特に, 鉄道車両工業は, 少量多品種生 産であり，近年はロボットやCAD/CAMの導入が行われて いるが, 設計から生産についても他の産業と比べ最新の技 術が採用し難いものであった。この状況を打破するため, 車両新造事業を開始するに当たっては, 製造する車両を当 面は通勤・近郊タイプのSUS車体に限定するなど, 効乷性 の向上を目指した工場として全体計画を策定し，製造の基 本となる開発・設計についても, ディジタル化による情報

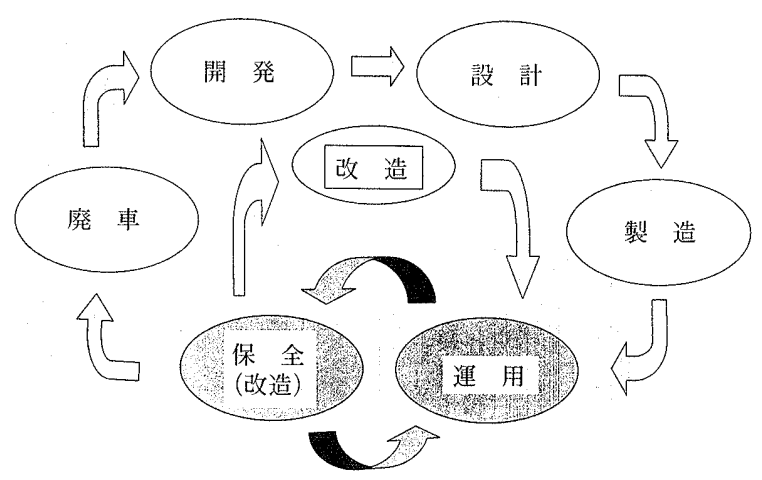

図 1 鉄道車両のプロダクトライフサイクル 
224

管理体制を導入, 生産管理とのリンクを計るなどのシステ ムを構築してきている。

今までの車両製造は, 複数のメ一カに発注し, 設計の担 当範囲を定め，それぞれがその範囲の設計に責任を持ち， でき上がった図面を相互に共有する形で進められていた。 この方法では，他社の担当している図面はでき上がらない と手に入らないため, 設計の進行状況が分かり難く, 生産 計画に合わせた生産準備が進め難いこととなる。そこで, 新形通勤車雨である209系950番台 (1998年12月落成：図 2) の設計では，当社の新津車両製作所と車両メ一カとの間で $\mathrm{CAD}$ ネットワークを介した共同設計（「協創設計」と名付け ている）を行い，両社の設計と製造がコンカレントに進行 するシステムを構築してきた ${ }^{(2)}$.

このシステム概念図を図 3 に示す。

この仕組みの基本コンセプトは,

（1）両社の図面，データ等の仕様統一による共有化

（2）共通データベースへの四面リリースによる共有化

（3）技術的検討情報の電子メ一ル化による伝達の迅速化

（4）出図管理等の責任と権限の明確化による図面管理 である。

具体的には，設計の進ちょく状況や出図期限を管理する 「プロジェクト管理データベース」, 会社間にまたがるCAD 図面の共有化を図る「設計データベース」等により構成さ れている.このシステムにより, 図面の検討内容, 進ちょ く等が早く確認でき，相互に干渉する図面の検討，チェッ クも迅速に実施できるようになった。 また，これらの情報 を生産管理システムにリンクすることで，コンカレントな 生産体制を構築するのであるが，生産管理はそれぞれの工 場等の設備や管理体制等により異なり，これを共通化する には限界があるため，それぞれの会社に㧊いて，この設計
データと生産準備データ等を独自の手法でリンクさせ管理 することとし,製造に関わるシステムは独自性を確保した ${ }^{(3)}$.

システムや，ツールは既存のものを活用し，新たな開発 は少ないが，それを運用する思想を両社が歩み寄ることで 構築できたものであり，前述のように「協創設計」と名付 けたものである。今後は, 他の分野で進められているよう に，関係企業間，すなわち車両メーカばかりでなく，部品 や電気機器メーカ等とのディジタルデータによる情報の共 通化, 共有化をはかり, 車両に関わる設計等のデータベー スを構築し, さらには資材調達等の分野へも拡大していく 必要がある。

新型通勤電車231系（前述の車雨の量産タイプ）におい てもこの手法で設計を奏施し，あわせて，プロトタイプの 運行によるさまざまなデータの蓄積, ユーザ側（運転，保 全等）の改善要望，お客様からの意見を設計に反映させる ため, 逐次, 要望を定型フォーマットにより転送し, 設計

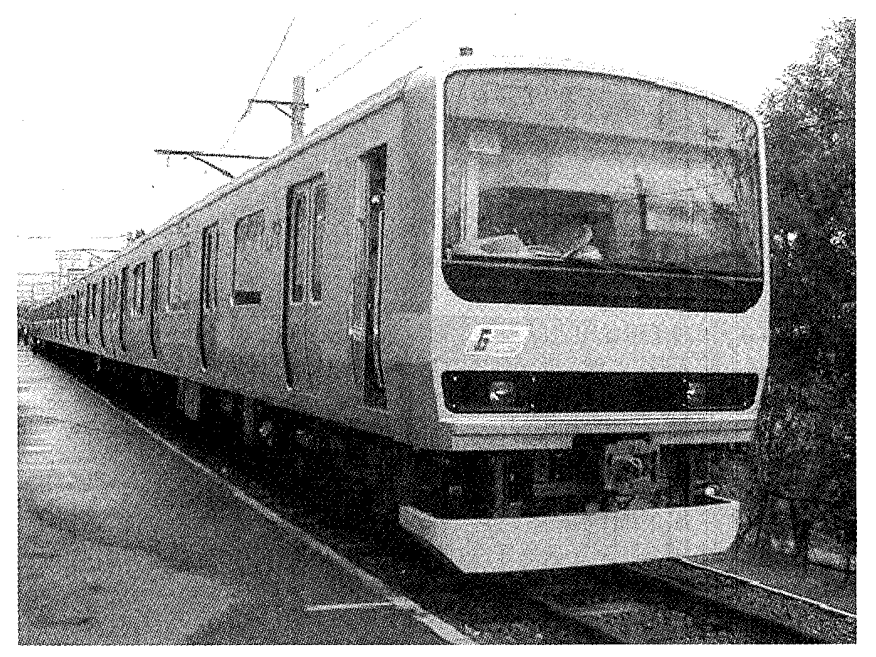

図 2 209系950番台車両（231系のプロトタイプ）

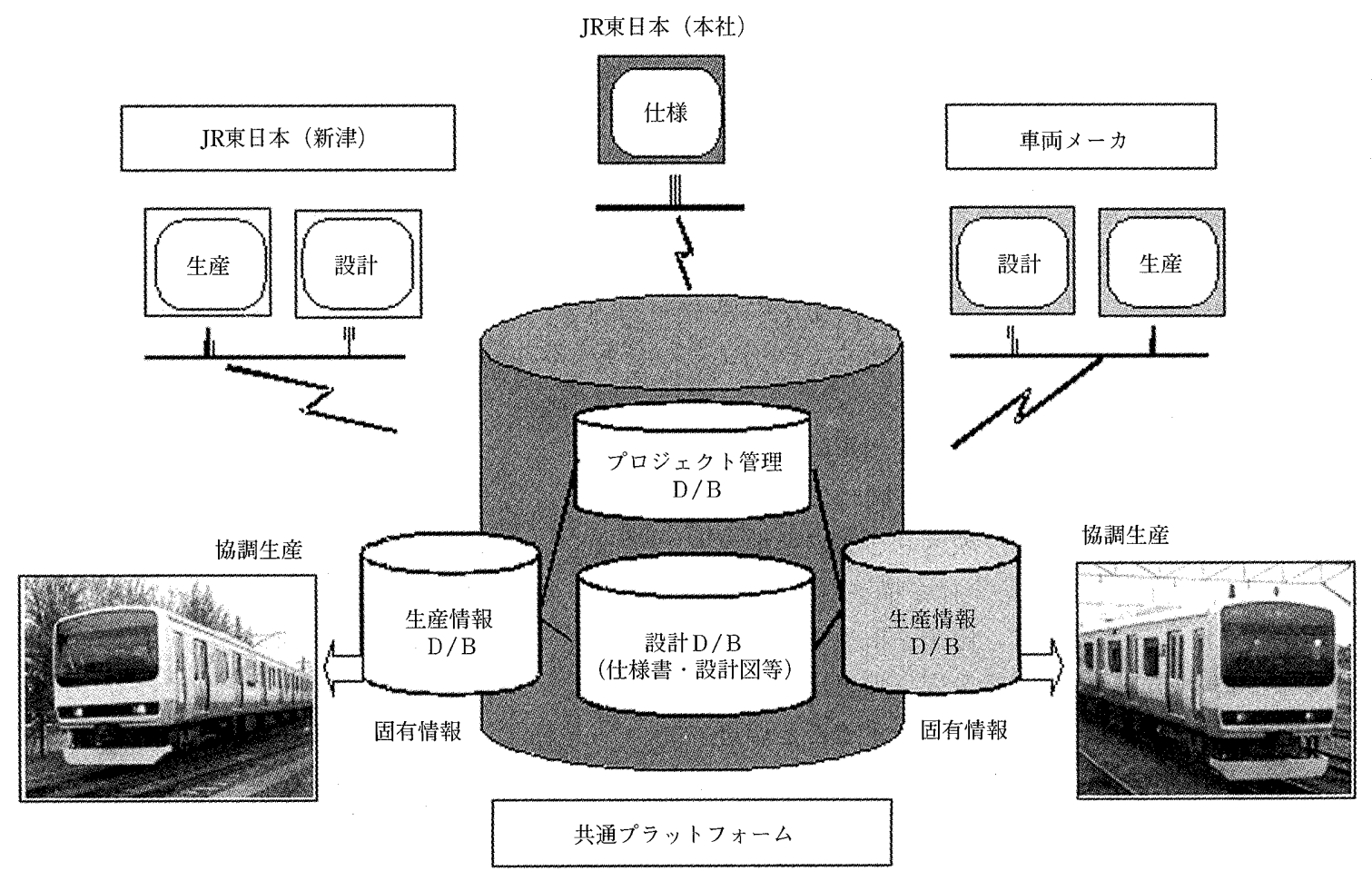

図 3 協創設計概念図 
サイドで検討・改善する手法を導入した，設計と製造だけ でなくユーザの意見をコンカレントに取り込み反映させる ということで, 高品質な商品の提供が可能となる.

\section{2-2 「改造」〜「設計」における情報化の取り組み}

現在はこのネットワークを当社の車両修繥工場ともリン クし，車両の改造を行う際の設計データの共有化により， 業務の效率化と設計精度の向上を図っている。広域に分散 する設計担当者が，一つのプラットフォームで共同作業す ることで，意思疎通と進ちょく管理を可能とした。

具体例として，運転保安装置の新規開発・車両改造時の 流れを示すと，

\begin{tabular}{|c|c|}
\hline 新造設計 (新津) & 新造車两の設計四 \\
\hline$\downarrow$ & \\
\hline 試験用に車両改造 & 計 (東京) \\
\hline$\downarrow$ & 上記図面より試験車改造図面 \\
\hline 改造予備用新造車 & の設計変更 (新津) \\
\hline$\downarrow$ & 最終仕様の設計に上記罒面活用 \\
\hline 既存車両の改造設 & (東京) \\
\hline
\end{tabular}

という流れ（かなりの部分は同時進ちょく）のなかで，デ 一タを共有することでの効率的設計が可能となり，材料準 備や施工要領畫作成等生産準備の迅速化がはかれている.

\section{2-3「連用」，「保年」における情楍化の取り組み}

車両のライフサイクルのなかで, 最も長期にかつ何度も 回転する閉ループであるのが運用〜保全である。車両を管 理する上で，必要な情報を車両配置区（日々の保守管理業 務等担当）と保全工場（オーバホール等担当）等の間で共 有化し, 車両の安全性, 安定性, 稼働率向上をはかること が求められていたため，その手段として「車両管理システ ム」導入し，各所をネットワーク化した。その概念を 図 4 に示す。これは, 現在までの車雨情報のデータベース 化および共有化であるが，管理している車両のデータばか りでなく他の車両で収集した同種のデータを使うことを可 能とし, より確実な信頼性分析による故障防止対策の夹施 や履歴管理による確実な計画の実施などの効果等を狙った ものである。

\section{3 今後の情報化の取り組み}

設計データのディジタル情報化などについては前述のよ うに充実しつつあるが，車両のライフサイクルを管理する 上で必要な情報は多種多様であり，その一部はディジタル データとして共有されているが，ネットワーク化の範囲が 限定されている。現在, 車両の開発·設計·製造段階で作り 上げるドキュメント類（説明書, 取扱マニュアル，応急处 置マニュアル等）についてもディジタル化を進めており， これらのデータを有機的に結合し

（1）車両に関する全般的技術情報がどこでも得られる

(2) 設計等技術データや写真等がどこでも得られる

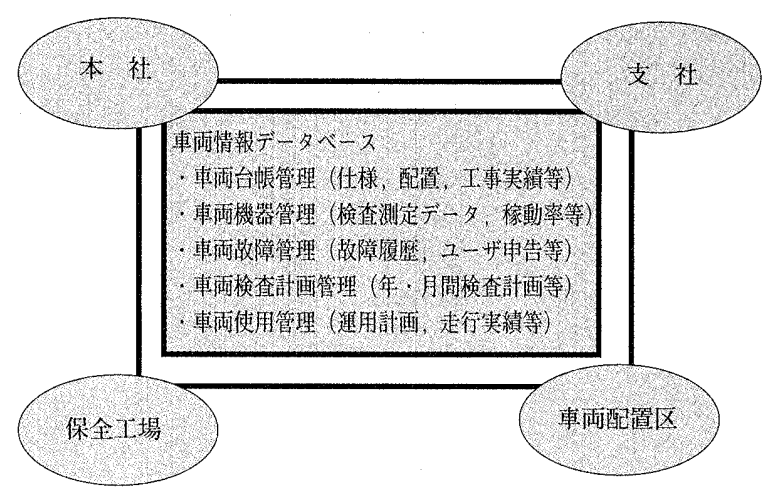

図 4 車両管理システムの概念

（3）車両に関するマニュアル類がどこでも得られ相互に リンクしている

（4）これらの情報が容易に改訂でき，簡単に検索できる 等の状況を作り出せば, 次のステップとして, 遠隔保全, アクティブマニュアル等の構築が可能となる，特に，鉄道 車両の製造，保守においてはウェアラブルコンピュータ ${ }^{(4)}$ の利用など情報通信機器活用による業務改善の効果は大き いと予想され，これらの情報化は今後の研究課題である.

また, 前述のライフサイクル内には大小数多くのループ が存在し, この中に打いても, 情報が常時共有化され, 次 の業務に生かされる体制を作る必要もある，例えば，運行 中の車两の状態情報が逐次，メンテナンス側に与えられれ ば，適切な対応が，迅速に行われるようになり，車両の稼 働率，信頼性，保守性が向上する。これにより，今までの 車両ごとに期間を定めて検査する体系から，機器ごとに信 頼性管理による適切な検査体系を導入できることとなる. 特に, 電子機器が多用されている最近の車両については, このような情報を管理する「状態監視型保全」に移行して いくことが鉄道事業者の課題の一つである。

\section{4. おわりに}

以上，単なる情報処理技術の実績でなく，鉄道車画のプ ロダクトライフサイクルにとっての情報化の必要性を事業 者としての立場で述べてきた。車両の開発・設計，鉄道に とって最も重要な技術の一つである保全，廃車など環境へ の影響等に関するライフサイクル全般の情報について, 目 的を明確にした「情報統合」という大きな視野での環境整 備に引き続き取り組んでいきたい。

（原稿受付 1999年12月28日）

\section{文 献}

(1) Kimura F., Life Cycle Design for Inverse Manufacturing, Proceedings of EcoDesign'99, (1999-2), 995-999.

（2）荒木美津夫，E231系協創設計について，平成11年鉄道技術 連合シンポジウム講演論文集，(1999), 71.

（3）村木克行，鉄道車両の設計・生産におけるコンカレントエン ジニアリングの実現に向けた情報システムの構築，WCRR'99 Book of Paper Summeries , 129.

（4）中井真品, ウェアラブル・コンピュータの実現と応用，日 本機械学会誌, 102-971 (1999), 607-610 